\title{
In Situ Synthesis of Graphene@cuprous Oxide Nanocomposite Incorporated Marine Antifouling Coating with Elevated Antifouling Performance
}

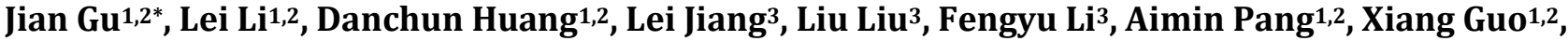 \\ Bowen Tao',2
}

${ }^{1}$ Science and Technology on Aerospace Chemical Power Laboratory, Xiangyang, China

${ }^{2}$ Hubei Institute of Aerospace Chemotechnology, Xiangyang, China

${ }^{3}$ Xiangyang Sunlavor Space Films Co. Ltd., Xiangyang, China

Email: *gu jian9804@163.com

How to cite this paper: $\mathrm{Gu}, \mathrm{J} ., \mathrm{Li}, \mathrm{L}$, Huang, D.C., Jiang, L., Liu, L., Li, F.Y., Pang, A.M., Guo, X. and Tao, B.W. (2019) In Situ Synthesis of Graphene@cuprous Oxide Nanocomposite Incorporated Marine Antifouling Coating with Elevated Antifouling Performance. Open Journal of Organic Polymer Materials, 9, 47-62.

https://doi.org/10.4236/ojopm.2019.93003

Received: June 4, 2019

Accepted: July 28, 2019

Published: July 31, 2019

Copyright $\odot 2019$ by author(s) and Scientific Research Publishing Inc. This work is licensed under the Creative Commons Attribution International License (CC BY 4.0).

http://creativecommons.org/licenses/by/4.0/

\begin{abstract}

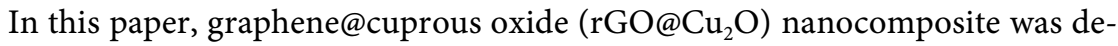
signed and prepared with graphene oxide, $\mathrm{CuSO}_{4}, \mathrm{NaOH}$ and L-ascorbic acid via an in-situ reaction process, and the as-prepared $\mathrm{rGO} @ \mathrm{Cu}_{2} \mathrm{O}$ nanocomposite was characterized by XRD, FT-IR, Raman spectroscopy, XPS, SEM-EDS and TEM. The results reveal that the $\mathrm{rGO} @ \mathrm{Cu}_{2} \mathrm{O}$ nanocomposite is of homogeneous distribution, and the $\mathrm{Cu}_{2} \mathrm{O}$ nanoparticles adsorbed on graphene sheets are with a fairly uniform size of $2.3 \mathrm{~nm}$. The $\mathrm{rGO} @ \mathrm{Cu}_{2} \mathrm{O} /$ acrylic resin self-polishing marine antifouling paint with functional surfaces was also prepared in this work, and a series of measurements were carried out for the obtained product. The WCAs of paint is up to $113^{\circ}$, and the adhesive force is averaged to $3.69 \mathrm{MPa}$. After being immersed into seawater, the whole bared panels show an abundant growth of marine organisms within 90 days, but the $\mathrm{rGO} @ \mathrm{Cu}_{2} \mathrm{O}$ paint coated surfaces are hardly fouled by marine organisms within 365 days. This work demonstrates that in situ synthesis of $\mathrm{rGO} @ \mathrm{Cu}_{2} \mathrm{O}$ is a tin-free potential alternative to inhibit biofouling.
\end{abstract}

\section{Keywords}

Graphene@cuprous Oxide Nanocomposite, Coating, Marine Antifouling, In Situ Synthesis, Panel Test

\section{Introduction}

At present, $95 \%$ of global bulk trade involves transport by sea with significant 
fuel consumption and corresponding exhaust emissions; marine corrosion and biofouling are becoming the predominating worldwide concerns for marine artificial infrastructures [1] [2] [3]. Of particularly marine biofouling is one of the major problems faced by the global industries, and several researchers have focused on developing novel paints or coatings for the preventing fouling of organisms [4] [5]. The marine biofouling normally refers to some harmful and wasteful accumulation and rapid growth of marine living matters, especially in summer time, on material surfaces immersed under seawater. Figure 1 illustrates the schematic representation of biofouling formation sequences, and such a biofouling process generally involves three stages as follows: 1) an initial accumulation of some organics is adsorbed on the surface, such as polysaccharide and protein; 2) the surface gradually is colonized by some living matters, such as bacteria, single-cell diatoms, protozoa and rotifer, to form a thin film of biological species; and 3) finally macro-foulers, such as barnacles, shellfish, tubeworms and macro-algae, settle and grow on the surface [6] [7] [8].

Biofouling can result in some devastating effects for various applications. For example, it can cause high frictional resistance leading to higher fuel consumption (up to 40\%), as well as the associated necessary and frequent hull maintenance schedules also cause extra economic losses. To remove them, a ship has to be more frequently dry-docked. In a nuclear power plant, the biofouling of its cooling water discharge pipe can greatly reduce its efficiency. In addition, the biofouling can also lead to bio-corrosion and invasion of alien aquatic species [8]. Controlling biofouling by applying antifouling coatings is a conventional measure, which can reduce the frictional drag and subsequently the fuel consumption as well as the greenhouse gases emissions [9].

Protective paint coatings for immersed parts of ship hulls include an antifouling topcoat which usually contains at least one biocidal agent [10]. According to the International Maritime Organization (IMO), a suitable biocide for use in an antifouling system should possess the following characteristics: broad spectrum activity, low mammalian toxicity, low water solubility, does not bio-accumulate in the food chain, does not persist in the environment, is compatible with paint raw materials, and has a favorable price/performance ratio [11]. Tributyltin self-polishing copolymer paints (TBT-SPC paints), such as tributyltin oxide and

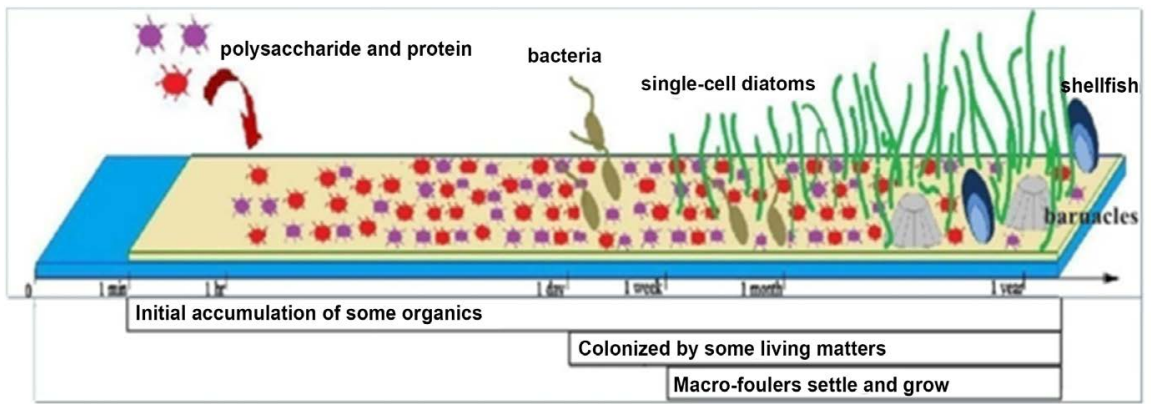

Figure 1. Schematic representation of biofouling formation sequences. 
tributyltin fluoride have ever been the most successful compounds against biofouling. They belong to organotin biocides which contain at least one tin-carbon bond. Unfortunately, TBT-SPC systems adversely affect the marine environment. Due to its high toxicity to molluscs, the use of tributyltin (TBT) has been restricted since 2008 [12]. Copper is an important metallic element to human health even though it is a relatively few groups of metals. Copper and copper compounds have been used since the 16th century as an effective biocidal agent due to its good marine ecological friendliness. As an antifouling coatings biocide, copper is known to protect marine immersed surfaces from tube worms, barnacles and most types of algal fouling. For some typical inorganic copper or cuprous compounds (such as $\mathrm{CuO}, \mathrm{CuS}, \mathrm{Cu}_{2} \mathrm{O}$ and $\mathrm{Cu}_{2} \mathrm{~S}$ ) used for the protection of ship hull, the copper or cuprous is released into the seawater in the form of copper ions $\mathrm{Cu}^{2+}$ or cuprous ions $\mathrm{Cu}^{+}$, but $\mathrm{Cu}^{+}$ions in the unsaturated state are liable to be oxidized immediately into $\mathrm{Cu}^{2+}$ ions under the seawater, which are the main biocidal form to the marine organisms [9] [13]. Kayano Sunada et al. [14] investigated the antiviral and antibacterial activities of various solid-state cuprous, cupric and silver compounds, and found that cuprous compounds specifically have much higher inhibitory activities than those of silver and cupric compounds. Cu-doped DLC films offered superior antibacterial activity against Escherichia coli and fungi [15]. Y. Liu et al. [16] found that the copper added in low dosage $(0.1 \%$ - 39.7\%) equips the copper-doped diamond-like carbon films with the capability of resisting effectively formation of protein-associated conditioning layer and additional killing of microorganisms by sustained release of copper ions.

Graphene, a unique two-dimensional mono-atomic-thick sheet of $\mathrm{sp}^{2}$ hybridized carbon, has recently been a dazzling star owing to its extraordinary properties, such as high electron mobility at room temperature, exceptional electric and thermal conductivity, excellent chemical stability, large specific surface area (SSA), superior mechanical properties and so on, and is regarded today as a very promising material for various applications in a vast range of nanotechnologies [17] [18] [19] [20] [21]. Graphene and its derivatives are now widely used in the fields of anti-corrosion paints, filtration membranes, conductive inks, as so on. Wang et al. [22] reported that the as-prepared superhydrophobic surfaces by using exfoliated graphene and polydimethylsiloxane have excellent self-cleaning property and much smaller corrosion current density, which exhibited unique anti-corrosion performance. Ramezanzadeh et al. [23] developed a highly crystalline and conductive GO-PANI composite and compared the effect of GO and GO-PANI composite on the corrosion protection performance and mechanism of ZRC. The GO-PANI composite was found to remarkably improve the electrical contact of zinc particles and steel substrate, leading to longer protection service life. Wang et al. [24] constructed a graphene oxide based thin film nanocomposite $\left(\mathrm{TiO}_{2} @ \mathrm{GO}\right)$ membrane for nanofiltration (NF), which was observed to possess superior NF performance in the case of $0.2 \mathrm{wt} \% \mathrm{TiO}_{2} @ \mathrm{GO}$ with water flux of $22.43 \mathrm{~L} \cdot \mathrm{m}^{-2} \cdot \mathrm{h}^{-1}$ at $0.4 \mathrm{MPa}$. Majee et al. [25] reported an efficient inkjet 
printing of water-based pristine GNPs ink. The combination of aqueous iodine doping and thermal annealing at elevated temperature can achieve an unprecedented DC conductivity of $\sim 10^{5} \mathrm{~S} \cdot \mathrm{m}^{-1}$ for inkjet printed GNPs films.

In our work, to take the advantage of the interconnected nanochannels between graphene nanosheets and the antifouling property of $\mathrm{Cu}_{2} \mathrm{O}, \mathrm{Cu}_{2} \mathrm{O}$ nanoparticles were introduced to enlarge the interlayer space of $\mathrm{GO}$ nanosheets. In situ synthesis of $\mathrm{rGO} @ \mathrm{Cu}_{2} \mathrm{O}$ nanocomposites was conducted through liquid phase method, which can avoid the aggregation and agglomeration of $\mathrm{Cu}_{2} \mathrm{O}$ nanoparticles on the resultant coatings, thus eliminating the negative effect of agglomeration. Subsequently, to further study the effect of $\mathrm{rGO} @ \mathrm{Cu}_{2} \mathrm{O}$ nanocomposite on coating structure and antifouling properties, a novel self-polishing marine antifouling coating with incorporating $\mathrm{rGO} @ \mathrm{Cu}_{2} \mathrm{O}$ into the acrylic resin was first designed and prepared. Different from conventional mainstream antifouling coatings containing $\mathrm{Cu}_{2} \mathrm{O}$, the antifouling coating developed in our work has much longer antifouling period because the $\mathrm{rGO}$ on the surface of $\mathrm{Cu}_{2} \mathrm{O}$ can control the release of $\mathrm{Cu}_{2} \mathrm{O}$ into the seawater and prolong the service life of $\mathrm{Cu}_{2} \mathrm{O}$.

\section{Experimental}

\subsection{In-Situ Synthesis of rGO@ $\mathrm{Cu}_{2} \mathrm{O}$}

Graphene oxide (GO) was synthesized by an improved Hummer's method, and the other chemicals used in this experiment were analytical grade. Firstly, $80 \mathrm{~mL}$ $1 \mathrm{mg} \cdot \mathrm{mL}^{-1} \mathrm{GO}$ aqueous solution was prepared by using ultrasonic cell crusher (output power of $1000 \mathrm{~W}$ at $\Phi 6$ frequency) for $2 \mathrm{~h}$. Then $100 \mathrm{~mL} 0.15 \mathrm{M} \mathrm{NaOH}$ solution was slowly dripped into the as-obtained GO solution to form a uniform dispersion under magnetic stirring at room temperature. Subsequently, $100 \mathrm{~mL}$ $0.10 \mathrm{M} \mathrm{CuSO}_{4}$ solution was gently dripped into the above solution to afford blue flocky precipitation. After $30 \mathrm{~min}$ magnetic stirring, $100 \mathrm{~mL} 0.10 \mathrm{M} \mathrm{L}$-ascorbic acid was slowly dripped into the above solution. The mixture was then stirred for a further $30 \mathrm{~min}$ under magnetic stirring to obtain the light yellow precipitation. The resulted precipitation was washed several times using copious ethanol and then dried overnight in the vacuum oven at $60^{\circ} \mathrm{C}$. The dried $\mathrm{rGO} @ \mathrm{Cu}_{2} \mathrm{O}$ was ground in an agate mortar for a few minutes to obtain $\mathrm{rGO} @ \mathrm{Cu}_{2} \mathrm{O}$ powder.

\subsection{Preparation of Self-Polishing Marine Antifouling Coating}

The self-polishing marine antifouling coating was prepared using the following process. First, $\mathrm{rGO} @ \mathrm{Cu}_{2} \mathrm{O}$ was added into acrylic resin and the solution was stirred for $0.5 \mathrm{~h}$ under ambient temperature. Then, some antifouling auxiliaries, pigments, wetting dispersants, rheological additives and solvents were added to form the final suspension. The suspension was stirred for another $0.5 \mathrm{~h}$ before use. At last, the suspension incorporated with curing agent was transferred to grinding miller to grind for $1 \mathrm{~h}$. In the following experiments, the solution was painted onto the steel substrate using a disposable Pasteur pipette, and cured at $30^{\circ} \mathrm{C}$ for $24 \mathrm{~h}$. 


\subsection{Characterizations}

$\mathrm{X}$-ray diffraction (XRD) was employed to analyze the crystalline phases of rGO@ $\mathrm{Cu}_{2} \mathrm{O}$ using a Rigaku D/max-2400 diffractometer with $\mathrm{Cu} K_{\alpha}$ radiation in the range of $2 \theta=10^{\circ}-80^{\circ}$ at a scanning speed of $15^{\circ} \cdot \mathrm{min}^{-1}$. Raman spectrum was conducted to investigate the fine structure of $\mathrm{rGO} @ \mathrm{Cu}_{2} \mathrm{O}$ in the frequency range of $500-2500 \mathrm{~cm}^{-1}$ using an inVia laser confocal Raman Microscope (Renishaw, UK) which equipped with a $532 \mathrm{~nm}$ laser source. Fourier-transform infrared (FT-IR) spectrum was recorded to analyze the chemical bonds of rGO@ $\mathrm{Cu}_{2} \mathrm{O}$ from 400 to $4000 \mathrm{~cm}^{-1}$ on a Nicolet Nexus-670 FTIR spectrometer. $\mathrm{X}$-ray photoelectron spectroscopy (XPS, Quantera, ULVCA-PHI) was used to determine the surface functionalities and elemental composition of $\mathrm{rGO} @ \mathrm{Cu}_{2} \mathrm{O}$. Scanning electron microscopy (SEM) observation and surface elements analysis were carried out on a FEI-Quanta 650 scanning electron microscope equipped with an energy-dispersive spectroscopy (EDS) detector under the electron acceleration voltage of $20 \mathrm{kV}$. The model of transmission electron microscopy (TEM) was FEI Tecnai $\mathrm{G}^{2} \mathrm{~F} 30$, and the electron acceleration voltage was set at $300 \mathrm{kV}$.

The water contact angles (WCAs) of marine antifouling coating containing $\mathrm{rGO} @ \mathrm{Cu}_{2} \mathrm{O}$ were measured by a SL200B contact angle meter at ambient temperature. The adhesion test was performed by cross cut method using cutter and pull-off method using an INSTRON1185 universal material testing machine, respectively. The former was done in three different regions on the surface of coating. The tensile velocity of the latter is $5 \mathrm{~mm} \cdot \mathrm{min}^{-1}$.

\subsection{Antifouling Evaluation}

The antifouling test in shallow submergence follows GB/T 5370-2007 procedure. Each steel panel $\left(300 \times 200 \times 3 \mathrm{~mm}^{3}\right)$ was ground with a sand paper. The coating was applied on each panel with a paint brush to form a thin film of $\sim 400 \mu \mathrm{m}$ in thickness. For each coating, three identical panels were fabricated and attached to a frame so that they were submerged in a different depths in the range 0.2 $2.0 \mathrm{~m}$ from a stationary experimental raft that was positioned in a sheltered bay with weak water currents (less than $\left.2 \mathrm{~m} \cdot \mathrm{s}^{-1}\right)$ at Xiamen, China $\left(24^{\circ} 45^{\prime} \mathrm{N}\right.$, $118^{\circ} 07^{\prime} \mathrm{E}$ ), on March 15, 2018. During each observation, the testing panels were taken out of the seawater, gently washed with seawater and photographed. We used the number of barnacles settled on each panel to quantify the marine biofouling extent because barnacles are the main macro-foulers on our panels.

\section{Results and Discussions}

\section{The Crystalline Phases of rGO@ $\mathrm{Cu}_{2} \mathrm{O}$ Nanocomposite}

Figure 2 shows the XRD patterns of the $\mathrm{Cu}_{2} \mathrm{O}$ and as-obtained $\mathrm{rGO} @ \mathrm{Cu}_{2} \mathrm{O}$ composite. As shown in Figure 2, the rGO@ $\mathrm{Cu}_{2} \mathrm{O}$ nanocomposite has a broad diffraction at $2 \theta=23.5^{\circ}$, which is assigned to the (002) crystal plane of reduced graphene [26]. The other diffraction peaks, such as $29.6^{\circ}, 36.4^{\circ}, 42.3^{\circ}, 61.4^{\circ}$, and $73.5^{\circ}$, correspond well with the crystal planes of (110), (111), (200), (220), and 


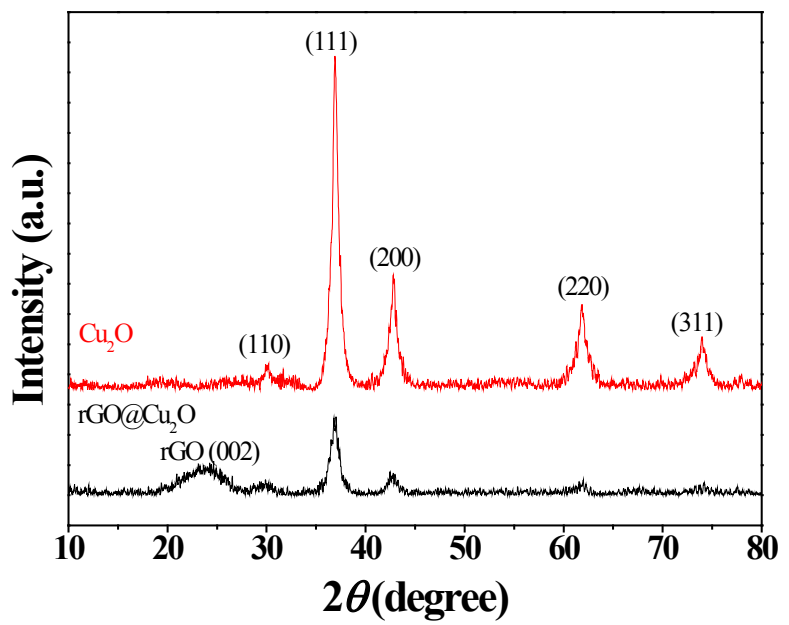

Figure 2. XRD patterns of $\mathrm{Cu}_{2} \mathrm{O}$ and $\mathrm{rGO} @ \mathrm{Cu}_{2} \mathrm{O}$.

(311) of crystalline $\mathrm{Cu}_{2} \mathrm{O}$, (JCPDS file No.05-0667). What is more, no diffraction peaks belonging to $\mathrm{Cu}$ or $\mathrm{CuO}$ are detected in the XRD pattern of the as-obtained rGO@ $\mathrm{Cu}_{2} \mathrm{O}$ nanocomposite, indicating that $\mathrm{L}$-ascorbic acid is an ideal reductant for the preparation of $\mathrm{rGO} @ \mathrm{Cu}_{2} \mathrm{O}$.

As a more powerful and surface-sensitive technique than XRD, Raman spectroscopy was conducted to investigate the fine structure of graphite and graphene materials. The Raman spectra of $\mathrm{GO}$ and $\mathrm{rGO} @ \mathrm{Cu}_{2} \mathrm{O}$ nanocomposite are shown in Figure 3.

Two well defined peaks are observed in both cases, at $1328 \mathrm{~cm}^{-1}$ and 1594 $\mathrm{cm}^{-1}$ for GO as well as $1349 \mathrm{~cm}^{-1}$ and $1592 \mathrm{~cm}^{-1}$ for $\mathrm{rGO} @ \mathrm{Cu}_{2} \mathrm{O}$ nanocomposite, which correspond to the well-documented D and G bands, respectively. The D band is attributed to the defects and lacks of an ordered arrangement in the graphene lattice, while the $\mathrm{G}$ band is attributed to the well-ordered layers and the first order scattering of the doubly degenerate $\left(\mathrm{E}_{2 \mathrm{~g}}\right)$ phonon mode symmetry of the $\mathrm{sp}^{2}$ hybridized carbon atoms [27] [28]. It is well known that the intensity ratio of $D$-band to $G$-band $\left(\mathrm{I}_{\mathrm{D}} / \mathrm{I}_{\mathrm{G}}\right)$ suggesting the defect density in graphene sample decreases when GO is reduced [29] [30]. In Figure 3, the $I_{D} / I_{G}$ ratio of $\mathrm{rGO} @ \mathrm{Cu}_{2} \mathrm{O}$ nanocomposite (0.98) is lower than that of GO (1.03), indicating that carbon network will be less disordered with fewer oxygen-containing groups. Moreover, the Raman shift at $635 \mathrm{~cm}^{-1}$ is assigned to $\mathrm{Cu}_{2} \mathrm{O}$, revealing the coexistence of $\mathrm{Cu}_{2} \mathrm{O}$ and graphene in the nanocomposite [31].

FT-IR analysis was applied to study the chemical bonds within the range of $400-4000 \mathrm{~cm}^{-1}$. The corresponding spectra of $\mathrm{Cu}_{2} \mathrm{O}$ and $\mathrm{rGO} @ \mathrm{Cu}_{2} \mathrm{O}$ are shown in Figure 4, respectively.

A sharp strong peak appears in both spectra, at $619 \mathrm{~cm}^{-1}$ for $\mathrm{Cu}_{2} \mathrm{O}$ and 624 $\mathrm{cm}^{-1}$ for $\mathrm{rGO} @ \mathrm{Cu}_{2} \mathrm{O}$, which is the characteristic peak of stretching vibration of the $\mathrm{Cu}-\mathrm{O}$ [32]. A weak peak is observed in the spectrum for $\mathrm{Cu}_{2} \mathrm{O}$ at $556 \mathrm{~cm}^{-1}$, which is not yet found in the spectrum for $\mathrm{rGO} @ \mathrm{Cu}_{2} \mathrm{O}$. We analyze that it may be a disturbance peak of impurities which can be released from the $\mathrm{Cu}_{2} \mathrm{O}$ during the high-speed stirring and grinding process, so it should be ignored. Besides, 


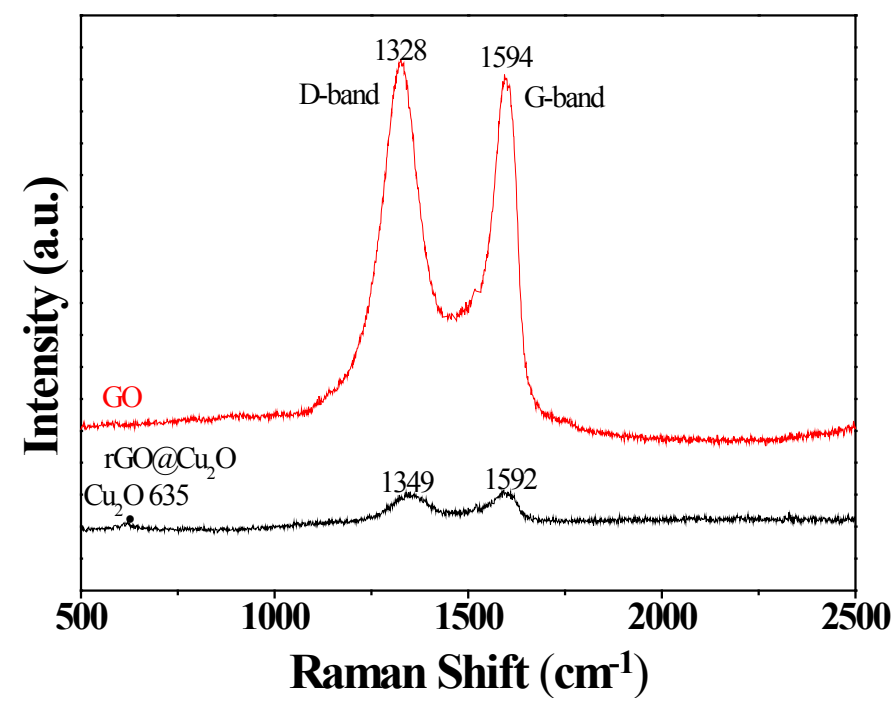

Figure 3. Raman spectra of GO and $\mathrm{rGO} @ \mathrm{Cu}_{2} \mathrm{O}$.

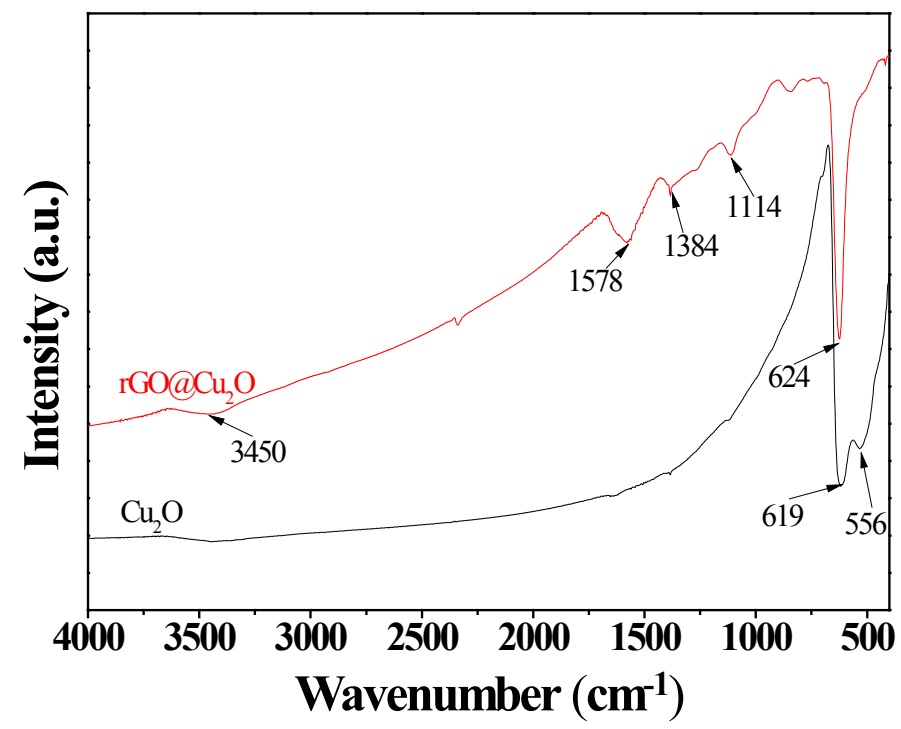

Figure 4. FT-IR spectra of $\mathrm{Cu}_{2} \mathrm{O}$ and $\mathrm{rGO} @ \mathrm{Cu}_{2} \mathrm{O}$.

rGO@ $\mathrm{Cu}_{2} \mathrm{O}$ nanocomposite demonstrates corresponding oxygen-containing groups from rGO. The band at $1114 \mathrm{~cm}^{-1}$ is identified as the bending vibration of $\mathrm{C}-\mathrm{O}-\mathrm{C}$, and that at $1384 \mathrm{~cm}^{-1}$ is assigned to $\mathrm{C}-\mathrm{OH}$ stretching vibration. In addition, the band at $1578 \mathrm{~cm}^{-1}$ can be attributed to the skeletal vibration of $\mathrm{C}=\mathrm{C}$ of the graphene sheets [33], indicating that $\mathrm{GO}$ is efficiently reduced by $\mathrm{L}$-acrobat acid. The band at $3450 \mathrm{~cm}^{-1}$ can be assigned to $\mathrm{O}-\mathrm{H}$ stretching vibration of weakly-bound water.

To further investigate the surface functional groups and elemental composition of as-obtained $\mathrm{rGO} @ \mathrm{Cu}_{2} \mathrm{O}$, XPS technique was used and the results were shown in Figure 5 and Table 1.

It is revealed by Figure 5(a) that there is a predominant graphite C1s peak and an O1s peak with the binding energy around $285 \mathrm{eV}$ and $531 \mathrm{eV}$, respectively. 


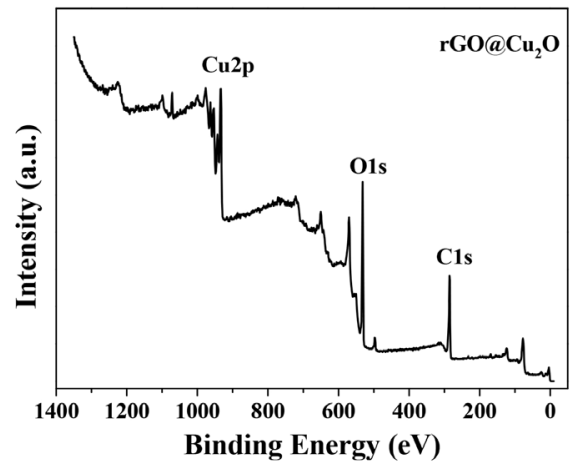

(a)

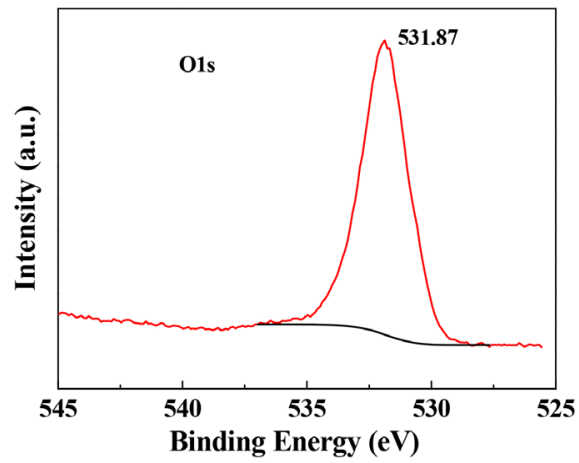

(c)

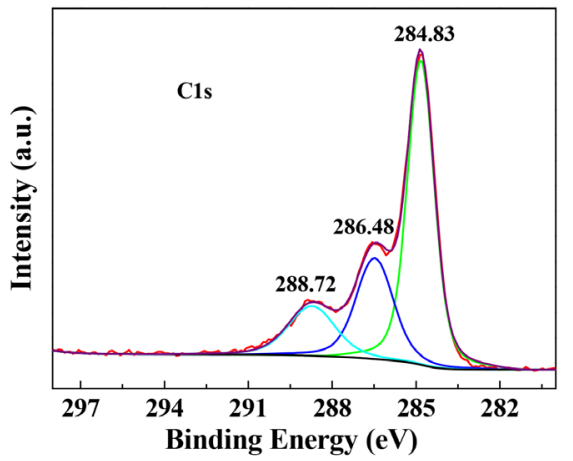

(b)

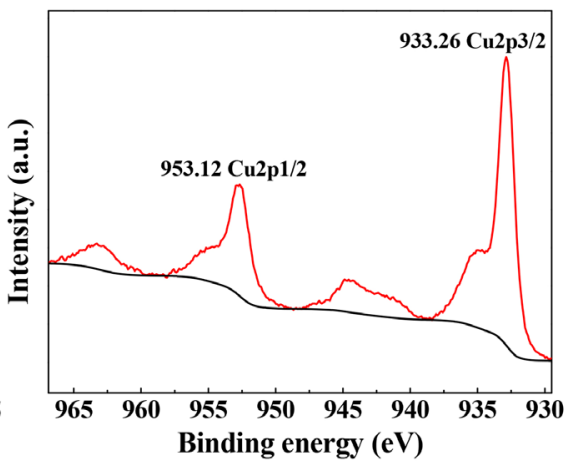

(d)

Figure 5. (a) Full scan XPS spectrum of rGO@ $\mathrm{Cu}_{2} \mathrm{O}$; (b) C1s XPS spectra; (c) O1s XPS spectrum; (d) Cu2p3/2 XPS spectrum.

Table 1. The surface elemental composition of $\mathrm{rGO} @ \mathrm{Cu}_{2} \mathrm{O}$.

\begin{tabular}{cccc}
\hline Element & Peak binding energy $(\mathrm{eV})$ & Atomic content $(\%)$ & $\mathrm{Cx} / \mathrm{Cc}(\%)$ \\
\hline $\mathrm{Cu} 2 \mathrm{p}$ & 933.26 & 11.53 & 21.7 \\
$\mathrm{O} 1 \mathrm{~s}$ & 531.87 & 35.24 & 66.2 \\
$\mathrm{C} 1 \mathrm{~s}$ & 284.83 & 53.22 & 100 \\
\hline
\end{tabular}

In Table 1 , the $\mathrm{O} / \mathrm{C}$ atomic ratio of $\mathrm{rGO} @ \mathrm{Cu}_{2} \mathrm{O}$ is $66.2 \%(35.24 \% / 53.22 \%)$, which is higher than that of conventional graphene. Meanwhile, a Cu2p peak with the binding energy about $933 \mathrm{eV}$ is also found, and an $11.53 \% \mathrm{Cu}$ atomic content is detected, which is derived from $\mathrm{rGO} @ \mathrm{Cu}_{2} \mathrm{O}$ nanocomposite. However, the lower $\mathrm{Cu} / \mathrm{C}$ atomic ratio $(21.7 \%)$ indicates the element $\mathrm{Cu}$ in the surface of $\mathrm{rGO} @ \mathrm{Cu}_{2} \mathrm{O}$ is very low, which is agreement with the XPS testing principle. Moreover, the high-resolution C1s spectra (Figure 5(b)) show strong XPS signals at $284.83 \mathrm{eV}(\mathrm{C}=\mathrm{C}, \mathrm{C}-\mathrm{C}$ and $\mathrm{C}-\mathrm{H}), 286.48 \mathrm{eV}(\mathrm{C}-\mathrm{O}-\mathrm{C}$ and $\mathrm{C}-\mathrm{OH})$ and $288.72 \mathrm{eV}(\mathrm{C}=\mathrm{O})$, indicating two different types of carbon bonds: graphitic $(\mathrm{C}=\mathrm{C}$ and $\mathrm{C}-\mathrm{C})$ and oxygenated $(\mathrm{C}-\mathrm{O}-\mathrm{C}, \mathrm{C}-\mathrm{OH}$ and $\mathrm{C}=\mathrm{O})$ on the surface of rGO@ $\mathrm{Cu}_{2} \mathrm{O}$. Figure 5(c) displays the existence of O1s spectrum, which corresponds to the oxygenated carbon bonds. Further analysis in Figure 5(d) shows the strong XPS signals of at $953.12 \mathrm{eV}$ and $933.26 \mathrm{eV}$, respectively, which are corresponding to the binding energy of $\mathrm{Cu} 2 \mathrm{p} 1 / 2$ and $\mathrm{Cu} 2 \mathrm{p} 3 / 2$ for $\mathrm{Cu}_{2} \mathrm{O}$, sug- 
gesting there are only cuprous ions $\left(\mathrm{Cu}^{+}\right)$on the surface of $\mathrm{rGO} @ \mathrm{Cu}_{2} \mathrm{O}$.

The morphology and size of the $\mathrm{rGO} @ \mathrm{Cu}_{2} \mathrm{O}$ nanocomposite were conducted through TEM and SEM observation. As shown in Figure 6(a), it can be clearly observed that the graphene sheets are well decorated with nearly spherical $\mathrm{Cu}_{2} \mathrm{O}$ nanoparticles, which disperse homogeneously in the $\mathrm{rGO} @ \mathrm{Cu}_{2} \mathrm{O}$ nanocomposite. In the reaction system, $\mathrm{Cu}(\mathrm{OH})_{2}$ tends to nucleate on the $\mathrm{GO}$ surface due to the abundance of functional groups on the GO sheets. Subsequently, spherical $\mathrm{Cu}_{2} \mathrm{O}$ nanoparticles are formed using L-ascorbic acid as the reductant. It is noted in Figure 6(b) that the particle size distribution of $\mathrm{Cu}_{2} \mathrm{O}$ nanoparticles is from 1.0 to $3.8 \mathrm{~nm}$ with average size of $2.3 \mathrm{~nm}$, indicating that the presence of GO in the system serves as a hard template to limit the growth of $\mathrm{Cu}_{2} \mathrm{O}$ nanoparticles.

Figure 7 shows the SEM image and EDS maps of $\mathrm{rGO} @ \mathrm{Cu}_{2} \mathrm{O}$. From the SEM image, we can see the $\mathrm{Cu}_{2} \mathrm{O}$ nanoparticles are anchored on the surface of rGO. In the EDS maps, the main elements in the $\mathrm{rGO} @ \mathrm{Cu}_{2} \mathrm{O}$ are $\mathrm{C}, \mathrm{O}$ and $\mathrm{Cu}$, which are agreement with the results of XPS test. Here, the $\mathrm{C}$ element only belongs to the $\mathrm{rGO}$, which indicates the $\mathrm{rGO}$ can adsorb on the surface of $\mathrm{Cu}_{2} \mathrm{O}$ excellently.

Currently, a lower surface energy implies a larger contact angle and less capability to interact spontaneously with hydrophobic materials [34]. In this study, the experiment parameters (temperature, preparation, roughness and surface cleanliness) were held constant when taking measurements. The mean static contact angles of the coated samples surface were obtained by at least five measurements taken at different positions. Figure 8 illustrates the WCAs of substrate, coating containing $\mathrm{Cu}_{2} \mathrm{O}$ and coating containing $\mathrm{rGO} @ \mathrm{Cu}_{2} \mathrm{O}$ with DI-water before immersion test, from which we can see the WCA of substrate with DI-water is about $45^{\circ}$, but that of coating containing $\mathrm{Cu}_{2} \mathrm{O}$ and $\mathrm{rGO} @ \mathrm{Cu}_{2} \mathrm{O}$ are $97^{\circ}$ and $113^{\circ}$, respectively. The reason is the rGO has low surface energy and good hydrophobicity, which weakens the wettability of $\mathrm{Cu}_{2} \mathrm{O}$ with water, leading to the increase of WCA for the marine antifouling coating. This indicates that both the low surface energy and micro/nanostructure play vital roles in maintaining hydrophobicity of the marine antifouling coating.
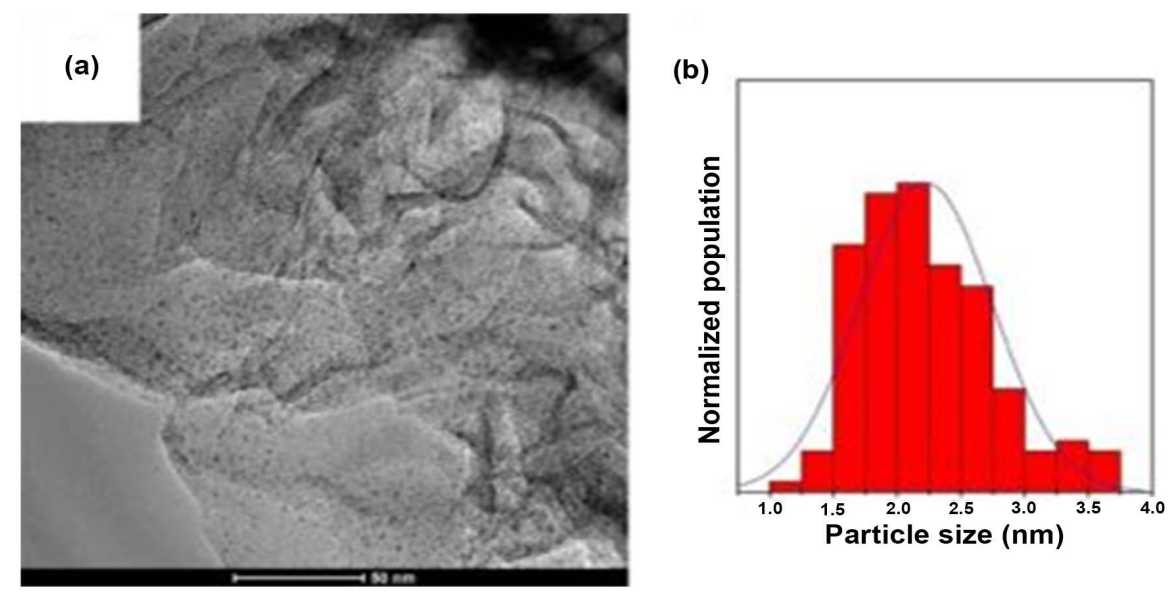

Figure 6. (a) TEM image of $\mathrm{rGO} @ \mathrm{Cu}_{2} \mathrm{O}$; (b) Size distribution histogram of $\mathrm{Cu}_{2} \mathrm{O}$ nanoparticles. 


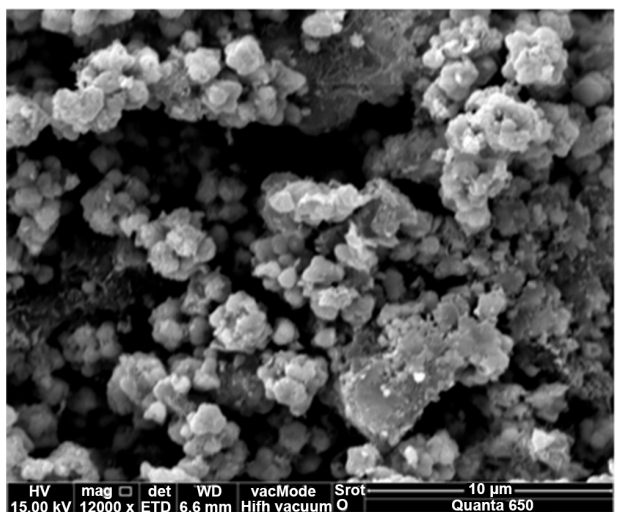

$\mathrm{OKa1}$

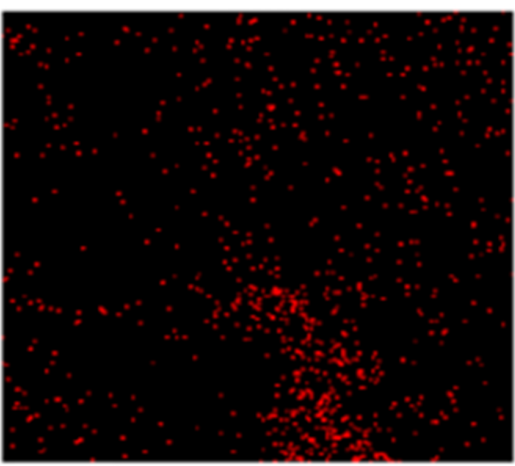

$\longdiv { 1 0 \mu m }$
C Ka1_2

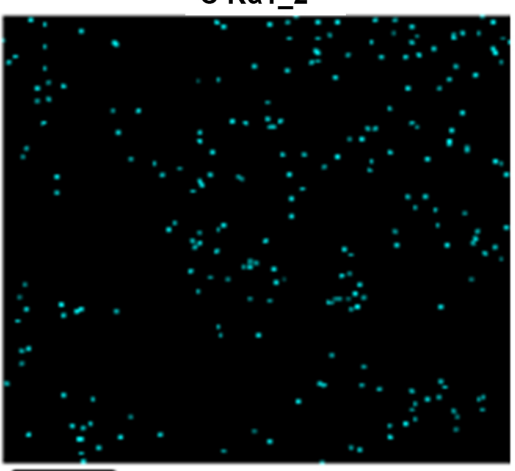

Cu La1_2

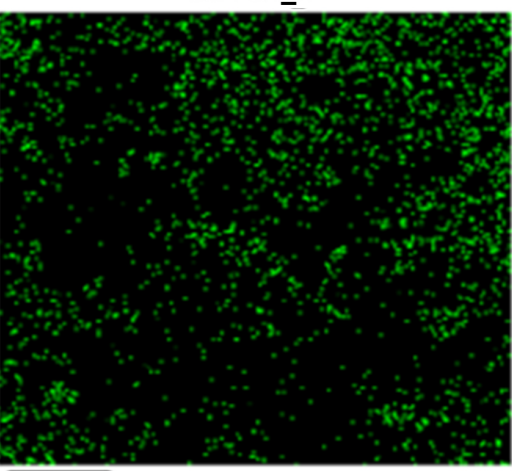

$10 \mu \mathrm{m}$

Figure 7. SEM image and EDS maps of $\mathrm{rGO} @ \mathrm{Cu}_{2} \mathrm{O}$.

(a)

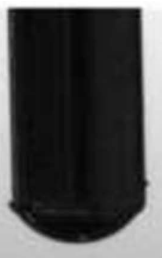

(b)

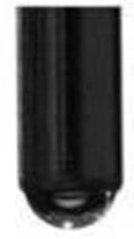

(c)
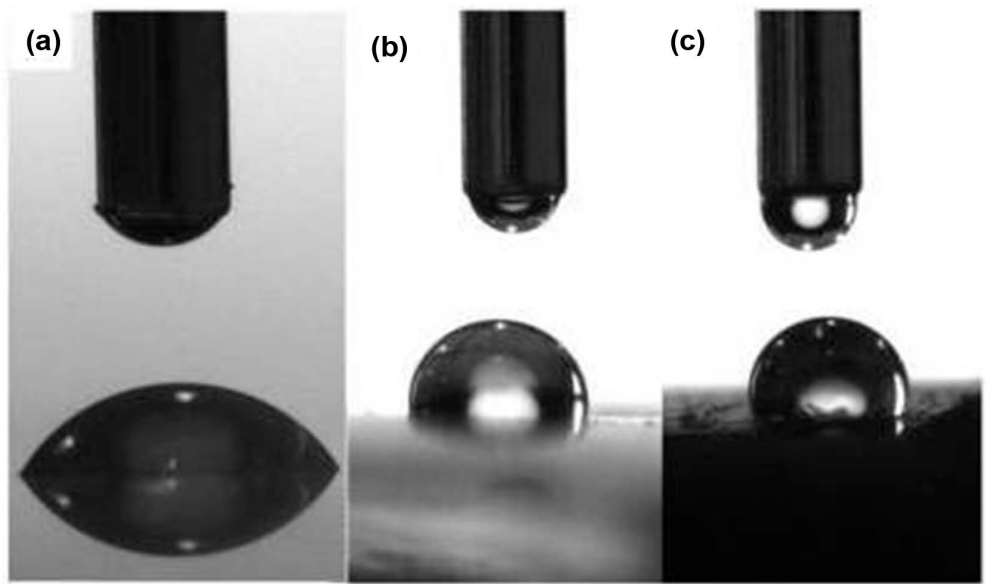

Figure 8. WCAs of (a) substrate; (b) coating containing $\mathrm{Cu}_{2} \mathrm{O}$; (c) coating containing rGO@ $\mathrm{Cu}_{2} \mathrm{O}$ with DI-water.

For the marine antifouling coating, whose adhesive force with intermediate coating is a key issue for its application in ships, marine devices, and so on, thus the adhesion property of marine antifouling coating containing $\mathrm{rGO} @ \mathrm{Cu}_{2} \mathrm{O}$ was further investigated. Figure 9 shows the adhesion test results by using cross cut method.

From the photos, it can be seen that the surface of original coating is very smooth. There are some scratches of cutting knife on the cut coating, and the 


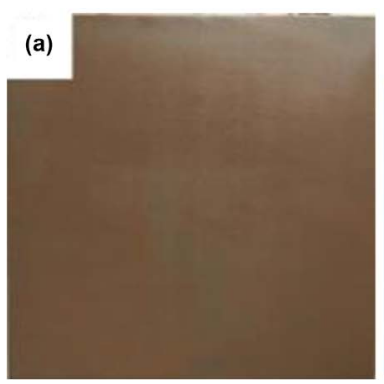

\section{(b)}

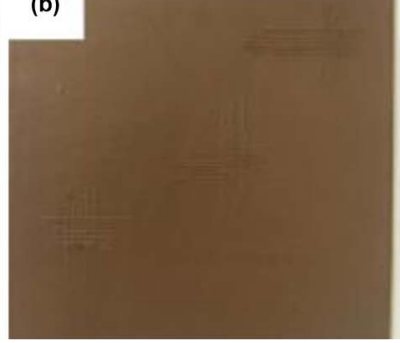

(c)

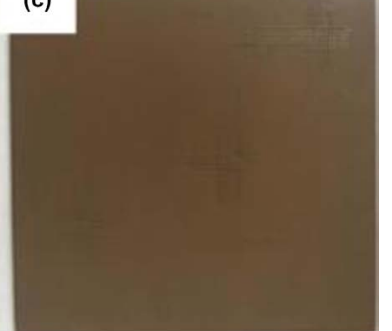

Figure 9. Test result of cross cut method (a) original sample; (b) cut sample; (c) cut sample after exfoliation with sticky tape.

incisions are almost not peeled off after exfoliation with sticky tape, which indicates the adhesion between marine antifouling coating and intermediate coating can meet the requirement of Class 1.

Additionally, the pull-off method was also used to test the adhesive force, and the results are shown in Table 2. The average adhesive force is $3.69 \mathrm{MPa}$, which is satisfied the engineering application.

Finally, the marine antifouling paints coated substrates are examined in the Xiamen for their marine antifouling applications. $\mathrm{Cu}_{2} \mathrm{O}$ is one of the well-known biocides and antibacterial agents over a wide spectrum of bacteria. Several studies on the $\mathrm{Cu}_{2} \mathrm{O}$ nanoparticles incorporated surfaces shown to be efficient antifouling growth inhibition coatings. Hence, we expected that the prepared coating with $\mathrm{rGO} @ \mathrm{Cu}_{2} \mathrm{O}$ might efficiently reduce the growth of marine organisms on its surface. The antifouling properties of the prepared coatings with $\mathrm{Cu}_{2} \mathrm{O}$ and $\mathrm{rGO} @ \mathrm{Cu}_{2} \mathrm{O}$ are measured by immersing the panels in a sheltered bay connected to the South China Sea. The bared panels are immersed for 90 days, and both the $\mathrm{Cu}_{2} \mathrm{O}$ and $\mathrm{rGO} @ \mathrm{Cu}_{2} \mathrm{O}$ paints coated surfaces are immersed for a period of 365 days. The fouling of marine organisms was observed visually as shown in Figure 10.

In Figure 10(a), the whole bared panels show an abundant growth of marine organisms within 90 days $(03.15 .2018-06.15 .2018)$ under the seawater, and there is no any intact area visible to the naked eye. After being immersed of 110 days, there are a few marine organisms on the $\mathrm{Cu}_{2} \mathrm{O}$ paint coated surfaces, but nothing is found on the $\mathrm{rGO} @ \mathrm{Cu}_{2} \mathrm{O}$ paint coated surfaces. With the extension of time, more and more marine organisms attach and grow on the $\mathrm{Cu}_{2} \mathrm{O}$ paint coated surfaces, as well as about $20 \%-25 \%$ continuous surfaces are covered with various marine organisms (in Figure 10(b)). The $\mathrm{rGO} @ \mathrm{Cu}_{2} \mathrm{O}$ paint coated surfaces, however, are hardly fouled by marine organisms from 0 to 365 days (in Figure 10(c)), which proves that the antifouling performance of $\mathrm{rGO} @ \mathrm{Cu}_{2} \mathrm{O}$ paint coated surfaces is better than that of the $\mathrm{Cu}_{2} \mathrm{O}$ paint coated surfaces.

\section{Antifouling Mechanisms}

For the marine antifouling coating, there are various explanations for its antifouling mechanism. In our work, we analyze the effect of $\mathrm{rGO} @ \mathrm{Cu}_{2} \mathrm{O}$ on the 
Table 2. Adhesive force between marine antifouling coating and intermediate coating.

\begin{tabular}{ccc}
\hline Test times & Tensile velocity $\left(\mathrm{mm} \cdot \mathrm{min}^{-1}\right)$ & Adhesive force $(\mathrm{MPa})$ \\
\hline 1 & 5 & 3.68 \\
2 & & 3.39 \\
3 & & 3.85 \\
4 & 3.92 \\
5 & 3.63 \\
\hline
\end{tabular}
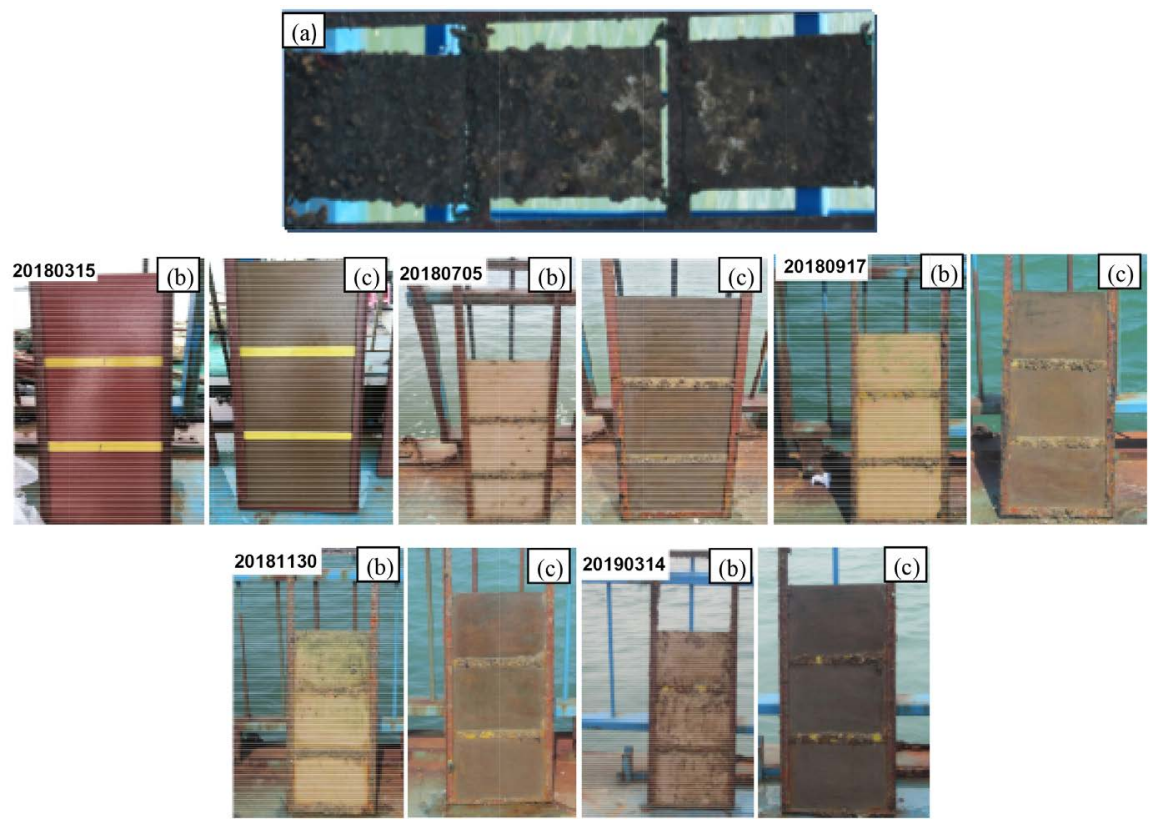

Figure 10. In situ marine fouling tests over a period in a sheltered bay connected to the south China sea. (a) Bared panels (90 days); (b) $\mathrm{Cu}_{2} \mathrm{O}$ paint coated surfaces ( 0 - 365 days) and (c) $\mathrm{rGO} @ \mathrm{Cu}_{2} \mathrm{O}$ paint coated surfaces (0 - 365 days).

antifouling performance, and the antifouling effect results from two aspects: one is from the biotoxicity of cuprous ions, and another is from mesoporation of rGO. The former is displayed in Figure 11.

$$
\begin{gathered}
\mathrm{Cu}_{2} \mathrm{O}+2 \mathrm{H}^{+}+4 \mathrm{Cl}^{-} \rightarrow 2 \mathrm{CuCl}_{2}^{-}+\mathrm{H}_{2} \mathrm{O} \\
\mathrm{CuCl}_{3}^{2-} \rightarrow \mathrm{CuCl}_{2}^{-} \rightarrow \mathrm{CuCl} \rightarrow \mathrm{Cu}^{+} \rightarrow \mathrm{Cu}^{2+}
\end{gathered}
$$

As shown in Equations (1) and (2), the cuprous ions are combined with chloride ions under the seawater condition, and finally oxidized into copper ions. The functions of copper ions are embodied in two faces: 1) copper ions can inactivate the main enzyme on which marine organisms depend; 2) copper ions make the biocellular protein flocculate and generate metal protein deposits.

More important, the graphene also plays an important role in the growth inhibition of marine organisms on the immersed part of ship hull. As is known to all, the graphene has unique layered nanostructure and super-large specific surface area, which can cover the surface of $\mathrm{Cu}_{2} \mathrm{O}$ fully. Therefore, on the one hand, 


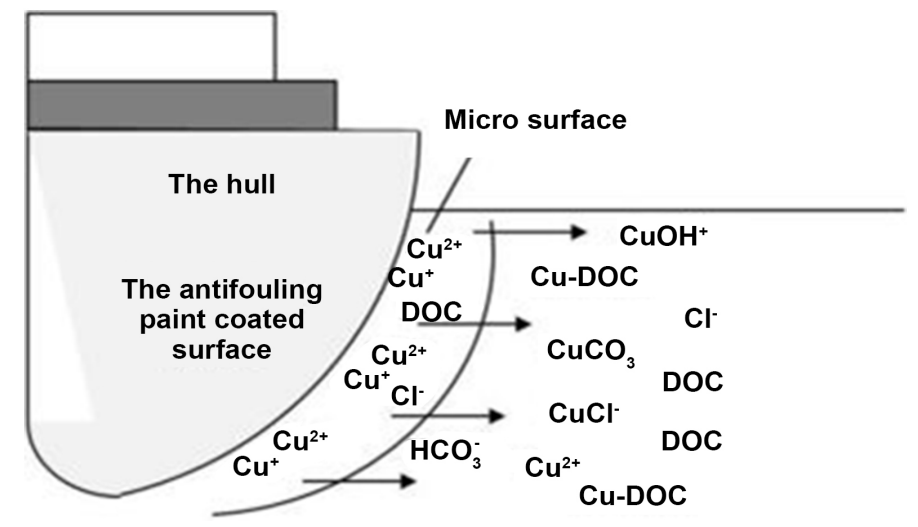

Figure 11 . The antifouling mechanism of coating with $\mathrm{Cu}_{2} \mathrm{O}$.

the graphene can make the $\mathrm{Cu}_{2} \mathrm{O}$ disperse homogeneously in the antifouling paints; on the other hand, the graphene also restrains the rapid release of $\mathrm{Cu}_{2} \mathrm{O}$ into seawater under the premise of minimum killing ability, which will certainly prolong the antifouling periods.

Based on the synergy of the two functions above, the marine antifouling coating containing $\mathrm{rGO} @ \mathrm{Cu}_{2} \mathrm{O}$ has preferable antifouling performance than that containing $\mathrm{Cu}_{2} \mathrm{O}$.

\section{Conclusion}

Marine antifouling paint is essential for the protection of ship hull from the biofouling of marine organisms. Herein, a facile process was established to prepare the self-polishing coating for marine fouling-released application by spraying composite paints on a steel substrate. The $\mathrm{rGO} @ \mathrm{Cu}_{2} \mathrm{O}$ nanocomposite was first in situ synthesized and then incorporated with acrylic resin in suitable solvents. The $\mathrm{rGO} @ \mathrm{Cu}_{2} \mathrm{O}$ nanocomposite is of homogeneous distribution, and the $\mathrm{Cu}_{2} \mathrm{O}$ nanoparticles adsorbed on graphene sheets are with a fairly uniform size of 2.3 $\mathrm{nm}$. The cross-linked network coatings present good adhesion, large WCAs and excellent antifouling performance. The WCAs of such coating is up to $113^{\circ}$, and the adhesive force is averaged to $3.69 \mathrm{MPa}$, which imply the marine antifouling coating has good hydrophobicity and adhesion property. Moreover, the antifouling performance of the coating was tested in a marine environment. It is observed that the whole bared panels show an abundant growth of marine organisms within 90 days, and $20 \%-25 \% \mathrm{Cu}_{2} \mathrm{O}$ paint coated surfaces are covered with various marine organisms, but the $\mathrm{rGO} @ \mathrm{Cu}_{2} \mathrm{O}$ paint coated surfaces are hardly fouled by marine organisms within 365 days. It may promise significant importance for the combination of $\mathrm{rGO} @ \mathrm{Cu}_{2} \mathrm{O}$ nanocomposite with acrylic resin in terms of the preparation of marine antifouling coating.

\section{Acknowledgements}

This work has been sponsored by CSIC Joint Fund, the Science and Technology on Aerospace Chemical Power Laboratory, and Hubei Institute of Aerospace Chemotechnology. 


\section{Conflicts of Interest}

The authors declare no conflicts of interest regarding the publication of this paper.

\section{References}

[1] Li, C., Atlar, M., Haroutunian, M., Anderson, C. and Turkmen, S. (2018) An Experimental Investigation into the Effect of $\mathrm{Cu}_{2} \mathrm{O}$ Particle Size on Antifouling Roughness and Hydrodynamic Characteristics by Using a Turbulent Flow Channel. Ocean Engineering, 159, 481-495. https://doi.org/10.1016/j.oceaneng.2018.01.042

[2] Soares, C.G., Garbatov, Y., Zayed, A. and Wang, G. (2009) Influence of Environmental Factors on Corrosion of Ship Structures in Marine Atmosphere. Corrosion Science, 51, 2014-2026. https://doi.org/10.1016/j.corsci.2009.05.028

[3] Brostow, W. and Hagg Lobland, H.E. (2017) Materials: Introduction and Applications. Ch. 19, John Wiley \& Sons, New York.

[4] Callow, J.A. and Callow, M.E. (2011) Trends in the Development of Environmentally Friendly Fouling-Resistant Marine Coatings. Nature Communications, 2, 244. https://doi.org/10.1038/ncomms1251

[5] Schultz, M.P., Bendick, J.A., Holm, E.R. and Hertel, W.M. (2010) Economic Impact of Biofouling on a Naval Surface Ship. Biofouling, 27, 87-98. https://doi.org/10.1080/08927014.2010.542809

[6] Chambers, L.D., Stokes, K.R., Walsh, F.C. and Wood, R.J.K. (2006) Modern Approaches to Marine Antifouling Coatings. Surface and Coatings Technology, 201, 3642-3652. https://doi.org/10.1016/j.surfcoat.2006.08.129

[7] Dobretsov, S., Dahms, H.U. and Qian, P.Y. (2006) Inhibition of Biofouling by Marine Microorganisms and Their Metabolites. Biofouling, 22, 43-54.

https://doi.org/10.1080/08927010500504784

[8] Xie, L.Y., Hong, F., He, C.X., Ma, C.F., Liu, J.H., Zhang, G.Z. and Wu, C. (2011) Coatings with a Self-Generating Hydrogel Surface for Antifouling. Polymer, 52, 3738-3744. https://doi.org/10.1016/j.polymer.2011.06.033

[9] Zhang, J.X., Pan, M.X., Luo, C.B., Chen, X.P., Kong, J.R. and Zhou, T. (2016) A Novel Composite Paint ( $\mathrm{TiO}_{2} /$ Fluorinated Acrylic Nanocmposite) for Antifouling Application in Amrine Environments. Journal of Environmental Chemical Engineering, 4, 2545-2555. https://doi.org/10.1016/j.jece.2016.05.002

[10] Lindholdt, A., Dam-Johansen, K., Olsen, S.M., Yebra, D.M. and Kiil, S. (2015) Effects of Biofouling Development on Drag Forces of Hull Coatings for Ocean-Going Ships: A Review. Journal of Coatings Technology and Research, 12, 415-444. https://doi.org/10.1007/s11998-014-9651-2

[11] International Maritime Organization (2002) Anti-Fouling Systems. In: Focus on $I M O$, International Maritime Organization, London, 1-31.

[12] Amara, I., Miled, W., Slama, R.B. and Ladhari, N. (2018) Antifouling Processes and Toxicity Effects of Antifouling Paints on Marine Environment: A Review. Environmental Toxicology and Pharmacology, 57, 115-130. https://doi.org/10.1016/j.etap.2017.12.001

[13] Zhao, W. and Wang, X. (2015) Antifouling Based on Biocides: From Toxic to Green. In: Antifouling Surfaces and Materials, Springer, Berlin, 105-134. https://doi.org/10.1007/978-3-662-45204-2_5

[14] Sunada, K., Minoshima, M. and Hashimoto, K. (2012) Highly Efficient Antiviral 
and Antibacterial Activities of Solid-State Cuprous Compounds. Journal of Hazardous Materials, 235-236, 265-270. https://doi.org/10.1016/j.jhazmat.2012.07.052

[15] Chan, Y.H., Huang, C.F., Ou, K.L. and Peng, P.W. (2011) Mechanical Properties and Antibacterial Activity of Copper Doped Diamond-Like Carbon Films. Surface and Coatings Technology, 206, 1037-1040. https://doi.org/10.1016/j.surfcoat.2011.07.034

[16] Liu, Y., Guo, P., He, X.Y., Li, L., Wang, A.Y. and Li, H. (2016) Developing Transparent Copper-Doped Diamond-Like Carbon Films for Marine Antifouling Applications. Diamond \& Related Materials, 69, 144-151. https://doi.org/10.1016/j.diamond.2016.08.012

[17] Geim, A.K. (2009) Graphene: Status and Prospects. Science, 324, 1530-1534. https://doi.org/10.1126/science.1158877

[18] Kalita, G., Ayhan, M.E., Sharma, S., Shinde, S.M., Ghimire, D., Wakita, K., Umeno, M. and Tanemura, M. (2014) Low Temperature Deposited Graphene by Surface Waveplasma CVD as Effective Oxidation Resistive Barrier. Corrosion Science, 78, 183-187. https://doi.org/10.1016/j.corsci.2013.09.013

[19] Novoselov, K.S., Falko, V.I., Colombo, L., Gellert, P.R., Schwab, M.G. and Kim, K. (2012) A Road Map for Graphene. Nature, 490, 192-200. https://doi.org/10.1038/nature11458

[20] Ning, J., Hao, L., Zhang, X.F., Liang, M.H. and Zhi, L.J. (2014) High-Quality Graphene Grown Directly on Stainless Steel Meshes through CVD Process for Enhanced Current Collectors of Supercapacitors. Science China, 57, 259-263. https://doi.org/10.1007/s11431-014-5455-y

[21] Gu, J., Zhang, X.P., Pang, A.M. and Yang, J. (2016) Facile Synthesis and Photoluminescence Characteristics of Blue-Emitting Nitrogen-Doped Graphene Quantum Dots. Nanotechnology, 27, Article ID: 165704. https://doi.org/10.1088/0957-4484/27/16/165704

[22] Wang, P., Yao, T., Sun, B., Fan, X.L., Dong, S.J., Bai, Y. and Shi, Y. (2017) A Cost-Effective Method for Preparing Mechanically Stable Anti-Corrosive Superhydrophobic Coating Based on Electrochemically Exfoliated Graphene. Colloids and Surfaces A: Physicochemical and Engineering Aspects, 513, 396-401. https://doi.org/10.1016/j.colsurfa.2016.11.002

[23] Ramezanzadeh, B., Moghadam, M.H.M., Shohani, N. and Mahdavian, M. (2017) Effects of Highly Crystalline and Conductive Polyaniline/Graphene Oxide Composites on the Corrosion Protection Performance of a Zinc-Rich Epoxy Coating. Chemical Engineering Journal, 320, 363-375. https://doi.org/10.1016/j.cej.2017.03.061

[24] Wang, J., Wang, Y.M., Zhu, J.Y., Zhang, Y.T., Liu, J.D. and Van der Bruggen, B. (2017) Construction of $\mathrm{TiO}_{2} @$ graphene Oxide Incorporated Antifouling Nanofiltration Membrane with Elevated Filtration Performance. Journal of Membrane Science, 533, 279-288. https://doi.org/10.1016/j.memsci.2017.03.040

[25] Majeea, S., Liu, C., Wu, B., Zhang, S.L. and Zhang, Z.B. (2017) Ink-Jet Printed Highly Conductive Pristine Graphene Patterns Achieved with Water-Based Ink and Aqueous Doping Processing. Carbon, 114, 77-83. https://doi.org/10.1016/j.carbon.2016.12.003

[26] Ananya, G., Pranati, N. and Ramaprabhu, S. (2016) Investigation of the Role of $\mathrm{Cu}_{2} \mathrm{O}$ Beads over the Wrinkled Graphene as an Anode Material for Lithium Ion Battery. International Journal of Hydrogen Energy, 41, 3974-3980. https://doi.org/10.1016/j.ijhydene.2016.01.015 
[27] Ferrari, A., Meyer, J. and Scardaci, V. (2006) Raman Spectrum of Graphene and Graphene Layers. Physical Review Letters, 97, 187401-187404. https://doi.org/10.1103/PhysRevLett.97.187401

[28] Gu, J., Zhang, X.P., Fu, L. and Pang, A.M. (2019) Study on the Hydrogen Storage Properties of the Dual Active Metals Ni and Al Doped Graphene Composites. International Journal of Hydrogen Energy, 44, 3936-3944. https://doi.org/10.1016/j.ijhydene.2019.01.057

[29] Yang, L.X., Li, Z.Y., Jiang, H.M., Jiang, W.J., Su, R.K., Luo, S.L. and Luo, Y. (2016) Photoelectrocatalytic Oxidation of Bisphenol A over Mesh of $\mathrm{TiO}_{2} / \mathrm{Graphene} / \mathrm{Cu}_{2} \mathrm{O}$. Applied Catalysis B: Environmental, 183, 75-85. https://doi.org/10.1016/j.apcatb.2015.10.023

[30] Raj Thiruppathi, A., Sidhureddy, B., Keeler, W. and Chen, A.C. (2017) Facile One-Pot Synthesis of Fluorinated Graphene Oxide for Electrochemical Sensing of Heavy Metal Ions. Electrochemistry Communications, 76, 42-46. https://doi.org/10.1016/j.elecom.2017.01.015

[31] Reimann, K. and Syassen, K. (1989) Raman Scattering and Photoluminescence in $\mathrm{Cu}_{2} \mathrm{O}$ under Hydrostatic Pressure. Physical Review B, 39, 11113-11119.

https://doi.org/10.1103/PhysRevB.39.11113

[32] Zhang, Y.C., Tang, J.Y., Wang, G.L., Zhang, M. and Hu, X.Y. (2006) Facile Synthesis of Submicron $\mathrm{Cu}_{2} \mathrm{O}$ and $\mathrm{CuO}$ Crystallites from a Solid Metallorganic Molecular Precursor. Journal of Crystal Growth, 294, 278-282. https://doi.org/10.1016/j.jcrysgro.2006.06.038

[33] Nethravathi, C. and Rajamathi, M. (2008) Chemically Modified Graphene Sheets Produced by the Solvothermal Reduction of Colloidal Dispersions of Graphite Oxide. Carbon, 46, 1994-1998. https://doi.org/10.1016/j.carbon.2008.08.013

[34] Azémard, C., Vieillescazes, C. and Ménager, M. (2014) Effect of Photodegradation on the Identification of Natural Varnishes by FT-IR Spectroscopy. Microchemical Journal, 112, 137-149. https://doi.org/10.1016/j.microc.2013.09.020 